\title{
THE RELATIONSHIP OF THE EFFECTIVENESS OF INTERPERSONALCOMMUNICATION, WORKING AGE AND JOB TENURE WITH ORGANIZATIONAL COMMITMENT
}

\author{
Vera Anitra ${ }^{1}$, Tri Astuti ${ }^{2} *$ \\ Fakultas Ekonomi, Hukum, Politikdan Psikologi ${ }^{1,2}$ \\ Universitas Muhammadiyah Kalimantan Timur, Kaltim, Indonesia ${ }^{1,2}$ \\ *Corresponding Author: tri497@umkt.ac.id
}

\begin{abstract}
The purpose of this study was to find the relationship between the effectiveness of interpersonal communication, working age and job tenure with organizational commitment. The method used in this study was a quantitative method using a questionnaire as a data collection tool. The data analysis used in this study is multiple regression analysis which was processed by a data analysis program called Statistical Package for the Social Sciences (SPSS). Participants in this study were employees at PT. Pupuk Kalimantan Timur with several predetermined criteria such as; regular employees and employees whose last education was high school or equivalent. The results of this study found that the effectiveness of interpersonal communication, working age and job tenure were able to predict employees' organizational commitment. Other results were the effectiveness variables of interpersonal communication was the most influential variable on increasing organizational commitment and then followed by variables of working age and job tenure. The results of this study are expected to be one of the strategies that can be used by companies to increase organizational commitment.
\end{abstract}

Keywords: organizational commitment, interpersonal communication, working age, job tenure

Received Juli ${ }^{15 t h} 2019 \quad$ Revision January ${ }^{6 \text { th }} 2020$ Accepted for Publication January ${ }^{12 \text { th }} 2020$

\section{INTRODUCTION}

Organization is a place which has important components, one of them is employees. The definition of organization according to Pace and Faules (1994) is an association of two or more people who carry out activities by following the rules made to achieve a common goal. The role of employees is to realize the organizational goals and objectives of the employees themselves. According to Nortcraft and Neale (1990), employees and organizations have a reciprocal relationship which means that the organization will run properly with employees as supporters in the success of the organization.

According to Muthuveloo and Rose (2005), the role of employees for a success in working, one of the factors, is work commitment. According to Robbins (2006), commitment is a condition of an individual who is in line with the organization and its goals and desires to maintain its membership in the organization. According to Gamble and Huang (2008), a committed worker plays an important role in the success of the organization. 
In 2004, the results of research conducted by consulting firm Watson Wyatt in Indonesia concluded that $35 \%$ of employees chose tostay in the company. This result shows that Indonesia ranks lowest for work commitments compared to countries in the Asia Pacific at $57 \%$ (Portalhr, 2004). Organizational commitment is a reflection of the extent to which individuals identify themselves and their goals towards the organization (Kreitner\&Kinicki, 2010). According to McShane and Glinow (2003), organizational commitment refers to the closeness of employees to identify the extent of their involvement in an organization. According to Roe, Solinger, and Olffen (2008), organizational commitment can be defined as a behavior in relation to the organization.

Organizational commitment is interesting to be studied, this is because problems often arise within work organizations that are always associated with turnover and absenteeism, so one important aspect in the organization is maintaining existence and reducing turnover. Tanajaya and Noegroho (1995) said that the presence of commitment in employees will benefit the organization, such as obtaining optimal support from employees and reducing costs in maintaining HR. This has an impact on reducing cases of absenteeism and reduced turnover. Employees who possess high commitment will view employment as a mean to work and develop themselves not as a burden or obligation because an employee is expected to be able to animate his job and work with his mind and heart.

Gamon (1991) explains that work commitment is formed based on two components, components originating from within (emotional aspects) and components from outside (aspects of behavior). Components originating from within refer to feelings of pride and obedience to the organization and the desire to continue to play a role in the organization. Components that come from outside explain loyalty and commitment to the organization as a process where an employee makes the decision not to leave the organization.

Steers and Porter (1983) statedthat the factors that influence organizational commitment are personal characteristics that include their level of education, job tenure and working age. According to Northcraft\& Neale (1990), there is a positive relationship between job tenure and organizational commitment. According to Van Dyne and Graham (2006), age affects work commitment, the olderthe employees are, the higher the level of commitment employees have.

Portalhr (2007), in the research conducted by consulting firm Watson Wyatt, one out of 5 organizations said that employees still chose to stay in the company at the age of 65 years, from the same survey, it mentioned, older employees still work for two reasons. First, fear of losing income after retirement, secondly, they really like working in that organization.

Employees as an important component are organized as individuals who have social relations between all levels of the organization and this is inseparable from the way they communicate with each other. According to Harcot, Krizan and Merrier (1996), administrators spend $95 \%$ of their working time communicating, where employees use $60 \%$ of their working period in various forms of communication. This shows the communication process in the organization can involve every member of the organization. According to Gamon (1991), communication among workers is important because communication is a principle that integrates all activities that occur being organized.

Hiltrop (1996), effective communication is one of the factors that influence organizational commitment. According to Burke and Nelson (1997), employees who are not 
being informed about their tasks that must be done, it can trigger misunderstandings about task issues, if this is allowed it can reduce commitment and distrust to management.

Organizations need communication in order to convey information. According to Rumanti (2002) communication is vertical (with leaders) or horizontal (peers) and the entire organizational environment. No success gained from poor communication; every success in the workplace is the end result of brilliant communication by all parties, both internally and externally.

Organizational success is caused by well-informed information. De Ridder and Van den Hoof (2004) found a positive relationship between communication and organizational commitment. In the meta-analysis conducted by Mathieu and Zajac (1990), it showed the importance of communication from leaders to create commitment, meaning that a leader must communicate each task clearly to his subordinates, thus employee commitment to the organization will tend to increase. Trombetta and Rogers (1988) stated the openness created by the leader to his subordinates and by informing all forms of tasks accurately, this can increase work commitment on employees. According to Putti, Aryee and Phua (1990) communication satisfaction was able to increase individual positive perceptions of the organization which meant that there was a positive relationship between communication created by various parties in the organization and employees' attachment to the organization.

In a study conducted by consulting firm Watson Wyatt, from 264 companies as respondents, they successfully identified six communication practices that encouraged the birth of top performers. This study found that companies that have effective communication programs, on average generate "total return to shareholders" (from 2002 to 2006) 47\% higher than organizations that have less effective communication. In addition, companies with good communication practices are reported to have a level of employee engagement four times higher than organizations that have poor communication. The six communication practices identified by the consulting firm Watson Wyatt can help improve performance in the company, such as focusing managers and employees on customer needs, establishing relationships with employees in conducting business, helping managers to communicate effectively, encouraging internal communication to be more effective, measuring the influence of employee communication, and marking employee experience (Portalhr, 2007).

Rho (2009) added that communication has an important impact on a work group or organization. Effective communication can increase organizational commitment, influence people's perceptions and opinions of the organization and positive perceptions that arise from employees.

The effectiveness of interpersonal communication in organizations is a dynamic process that serves as the main tool for organizational success related to the task. Pincus (1986) found that communication is positively related to commitment. Therefore maintaining employee commitment is a high priority for the organization because productive and trained employees can contribute a big role and value in organizational productivity, besides that in terms of commitment, employees who have high commitment also have the desire to stay in the organization and strives to help achieve organizational goals and help advance the organization. They also lack the tendency to leave the organization. The high level of organizational commitment held by employees is related to the low turnover of employees within an organization (Northcraft\& Neale, 1990). 
In this study, organizational commitment is the dependent variable, with the effectiveness of interpersonal communication, working age and job tenureas the independent variable. The problem highlighted in this study was whether the effectiveness of interpersonal communication, working age and job tenure had a relationship with organizational commitment.

\section{LITERATURE REVIEW}

According to Kreitner and Kinicki (2010), job tenure is positively related to organizational commitment, this is because working in a long period will tend to make an employee feel more at home in an organization, this is due to the fact that they have adapted to their environment long enough so that an employee will feel comfortable with their job. Other reasons are also due to the policies of agencies or companies regarding the guarantee of life on their retirement. According to Miner (1992), job tenure is also related to organizational commitment. Employees who have long working period will have relationship that has been built both with the workplace and fellow coworkers. Working relationships that have been established for years strengthen the emotional bond between the parties involved and this makes employees have high organizational commitment.

According to Luthans (2002), working age affects the level of organizational commitment. The higher the age of an employee is, the higher the employee's commitment to the organization where he works will be. This is because the opportunity for individuals to get other jobs becomes more limited as the age increases. According to Van Dyne and Graham (2006), age affects work commitment, the higher the age of employees the higher the commitment that employees have, this is due to what employees have given as long as they work so considerations about morale and material are very much considered.

According to several studies regarding the relationship between interpersonal communication and organizational commitment as stated by Matin et al. (2010) in his research conducted at JahadKeshavarzi's office with 52 subjects and Qom universities with 50 subjects with random sampling, there are links to the components of interpersonal communication and organizational commitment, because there is a high correlation between interpersonal components of communication skills, correlation between one component and organizational commitment is calculated using partial correlation.

According to Varona (1996) in his research conducted on three different organizations located in the city of Guatemala using 302 subjects, in this study it was stated that there was a positive relationship between interpersonal communication and organizational commitment. This is supported by research conducted by Hiltrop (1996), as for the factors that influence organizational commitment, such as effective communication within the organization.

According to Chen, Chen and Yeh (2003) with the results of his research that communication relates to trust so that this will have an impact on commitment, the research conducted in NSW Australia is a significant relationship between communications related to trust and organizational commitment.

Downs (1990) also examined the relationship of interpersonal communication with organizational commitment in two organizations in Australia. The results of these studies had a positive relationship between communication and organizational commitment. The factors 
that mostly influence employees' commitment are surveillance communication, communication for opinion and the climate of the communication.

Burnetto and Wharton (2003) in their study involving 178 low ranking police officers. Found out that communication influenced the stage of their work commitment. Good communication carried out by superiors to subordinates provides information that can be received by subordinates. In this study, communication was also studied in six dimensions related to police tasks, namely frequency of communication, informal communication, customer interactions, work interactions, and formal interactions.

Rho (2009) also added that communication has an important impact on a work group or organization. Effective personal communication will improve organizational results, communication can affect people's perceptions and opinions of the organization, perceptions that arise from employees will shape employees to become committed and improve their performance.

The meta-analysis research conducted by Mathieu and Zajac (1990) showed the importance of leader communication to create commitment, meaning that a leader must be on time and communicate each task clearly to his subordinates, thus, employee commitment to the organization will tend to rise.

According to Spaho (2011) the most important role of the effectiveness of interpersonal communication is building relationships that will provide a strong foundation in dealing with organizational change. This will increase employees' morale and contribute to the organization's strategic goals, effective communication is very important for the creation of a successful company. Poor communication between managers and employees will lead to conflicts within the company that will further lead to moral decline and ultimately not possible to achieve the company's strategic goals.

\section{Research Hypothesis}

$\mathbf{H}_{1}$ : There is a relationship between the effectiveness of interpersonal communication, working age and job tenure with organizational commitment

\section{RESEARCH METHOD}

\section{Research design}

This study used quantitative method to answer research questions. Quantitative research aims to test a theory and can describe statistics from facts and can show relationships between variables. This research can also be used to develop concepts, understandings and describe many things (Subana\&Sudrajat, 2005). The process of analyzing data from this study was divided into two stages. The first stage included descriptive analysis to describe data distribution while the second stage included testing hypotheses using multiple regression analysis. Regression analysis is one statistical analysis that is often used to analyze the relationship between two or more variables. According to Drapper and Smith (1992) regression analysis is an analytical method that can be used to analyze data and draw meaningful conclusions about the relationship of dependence variable on other variables by using Statistical Product and Service Solutions (SPSS) program to check the validity, reliability and relationship between variables in it. 


\section{Population and Samples}

Population is a number of people who at least have one similar characteristic that distinguishes them from other subjects (Hadi, 2004). The subjects in this study were 50 employees of PT. Pupuk Kalimantan Timur with a minimum work period of one year and at least have graduated from high school or equivalent level of education which also acted as a population that meansthey will be subject to generalization of this study's result (Azwar, 2010).

In a study, there is no need to take data from the entire population, taking sample which is part of the population is enough to be analyzed (Azwar, 2010) in which the sample is not a duplicate of the population but as a reflection that is viewed to describe the population optimally (Hadi, 2004). The sampling technique used in this study was random sampling in which the samples were chosen indiscriminately (Hadi, 2004). Random sampling was used because each subject in the population in this study had an equal opportunity to be selected as a sample (Azwar, 2010).

\section{RESULTS AND DISCUSSION}

\section{Description of the Quality of the Measuring Instrument}

The scale used in this study is the scale of organizational commitment and the scale of effectiveness of interpersonal communication. The preparation phase in this study included the implementation of a second scale trial on subjects that have the relatively similar characteristics. The purpose of the scale trial was to find out the reliability of the two scales. Item analysis and reliability of Cronbach's alpha using Statistical Product and Service Solutions (SPSS) software version 16.0 for Windows. The trial of scale of organizational commitment and the scale of effectiveness of interpersonal communication was carried out on 40 employees of PT. Pupuk Kalimantan Timur. This trial took place on Monday, December 19, 2011.

The scale of organizational commitment produced the value of Cronbach's alpha reliability coefficient of 0.886 and the effectiveness scale of interpersonal communication produces the Cronbach alpha reliability coefficient of 0.889 .

\section{Hypothesis testing}

Multiple regression analysis was conducted to determine the relationship between the effectiveness of interpersonal communication, working age and job tenure with organizational commitment using the Statistical Product and Service Solutions (SPSS) program version 16.0 for Windows. The hypothesis of this study is that there is a positive relationship between the effectiveness of interpersonal communication, working age and job tenure with organizational commitment. The higher the effectiveness of employee interpersonal communication, working age and job tenure is, the higher the employee's commitment to the organization will be.

The results of data analysis showed $r=0.739$ with $(p<0.01)$. Based on the results of the multiple regression analysis, the research hypothesis is accepted. It can be concluded that there was a positive and significant relationship between the effectiveness of interpersonal communication, working age and job tenure with organizational commitment. This shows that the higher the effectiveness of interpersonal communication, working age and job tenure 
with organizational commitment is, the higher the organizational commitment will be. The value of $\mathrm{R}^{2}=0.546$, shows the effectiveness variable of interpersonal communication, working age and job tenure effectively contribute to organizational commitment that is equal to $54.6 \%$ and the remaining $45.4 \%$ is influenced by other variables.

The effective contribution of each variable, namely the effectiveness of interpersonal communication, working age and job tenure with organizational commitment can be known by using calculations using the following formula:

$$
S E x_{i}=\frac{B x_{i} \cdot C P x_{i} \cdot R^{2}}{\text { Regression }}
$$

Description:
$\mathrm{Bx}_{\mathrm{i}}$
: Coefficient B Component $\mathrm{x}$
$\mathrm{Cpx}_{\mathrm{i}} \quad$ : Cross product Component $\mathrm{x}$
Regression : Regression Value
$\mathrm{R}^{2} \quad: \mathrm{R}$ square (total of effective contribution)

Based on the output table of Statistical Product and Service Solutions (SPSS) version 16.0 for Windows, regression analysis revealed several coefficients which can be seen in table 1.1.

Table1.1

Effective Contributing Coefficient Calculation

\begin{tabular}{|l|c|c|c|c|}
\hline \multicolumn{1}{|c|}{ Variabel } & B & Cross Product & Regression & R Square \\
\cline { 1 - 3 } $\begin{array}{l}\text { Effectiveness of } \\
\text { Interpersonal } \\
\text { Communication }\end{array}$ & 0,698 & 1073,600 & & \\
\cline { 1 - 3 } Working Age & 0,016 & 224,600 & & \multirow{2}{*}{$0,562.232$} \\
\cline { 1 - 3 } Job Tenure & 0,053 & 183,000 & & \\
\hline
\end{tabular}

The results of the calculation of the effective contribution formula found that the effectiveness of interpersonal communication made an effective contribution of 0.537 or $53.7 \%$, and working age gave an effective contribution of 0.0026 or $0.26 \%$ and the period of working provided an effective contribution of 0.0069 or $0.69 \%$.

\section{Discussion}

The results of the description analysis show that the effectiveness of interpersonal communication empirically (80.9) is higher than the hypothetical mean with categorization at a very high level for the effectiveness of interpersonal communication which was up to 30 $(60 \%)$ out of the 50 research subjects. The results of the description analysis show that the empirical mean of organizational commitment (65.8) is higher than the hypothetical average 
(48), with categorization at a very high level for organizational commitment which amounts to 33 employees $(66 \%)$ of 50 research subjects.

The descriptive analysis above shows that the effectiveness of interpersonal communication shows the dynamics of organizational commitment variables in the very high category on the other hand the effectiveness of interpersonal communication is also in a very high category.

Based on the results of the assumption test in the form of normality test and linearity test in this study, the results show that the relationship between the effectiveness of interpersonal communication, working age and job venture is linear.

Hypothesis testing was carried out by using multiple regression analysis. The correlation of the results of this study is $r=0.739$ and $(p<0.01)$, this indicates that there is a positive and significant relationship. The value of $\mathrm{R}^{2}=0.546$, this indicates that the contribution given by the effectiveness of interpersonal communication, age and years of service to organizational commitment is equal to $54.6 \%$. Thus, it can be seen that other variables of $45.4 \%$ outside of the variable of the effectiveness of interpersonal communication, working age and job tenure provide a smaller contribution to the emergence of organizational commitment.

These results indicate that the effectiveness of interpersonal communication, working age and job tenure can influence the organizational commitment of employees of PT. Pupuk Kalimantan Timur.

The results of this study are in accordance with the research of Steers and Porter (1983) stating that the factors that influence organizational commitment are personal characteristics which include education, work period and age. According to Northcraft and Neale (1990), employees who are highly committed will put greater effort in order to carry out the tasks assigned to them and tend to continue working with his organization for a long time. In the study, there is a positive correlation between the level of organizational commitment that employees have and employees' job tenure. Van Dyne and Graham (2006), age affects work commitment, the higher the age of the employee is, the higher the level of commitment that employees have, and this is due to what employees have given throughout their working period so considerations about morale and material are very much considered.

This result is also in accordance with several studies as in the research of Matin et al. (2010), in JahadKeshavarzi's office with 52 subjects and Qom university with 50 subjects with random sampling, that there are links to the components of interpersonal communication and organizational commitment, there is a positive correlation between the components of interpersonal communication with organizational commitment, the correlation between one components and organizational commitment are calculated using partial correlation.

According to Armstrong (1998), communication by superiors to subordinates not only contains job information but also contains the formation of good relationships (relationship building). The results of Prasetyo's research, Nurtjahjanti and Indrawati (2005), a good and harmonious relationship between management and employees and employee to employee will provide a good climate in an effort to build and increase on employees' commitment to the organization. According to De Ridder and Van den Hoof (2004), organizational success is caused also by well transferred information to the organization; this is to carry out tasks 
related to the information exchange. According to Verona (1996), there was a positive relationship between interpersonal communication and organizational commitment.

Burnetto and Wharton (2003) in their study involving 178 low ranking police officers. In this study, the obtained results were that communication influenced the stage of their work commitment. Good communication carried out by superiors to subordinates, providing information that can be received by subordinates. In this study communication was also studied in six dimensions related to police tasks, such as frequency of communication, informal communication, customer interaction, work interaction, and formal interaction. The meta-analysis research conducted by Mathieu and Zajac (1990) shows the importance of leader communication to create employee work commitments, meaning that a leader must communicate each task clearly to his subordinates, thus, employee commitment to the organization will tend to increase.

According to Trombetta and Rogers (1988) the openness created by the leaders on subordinates and by accurately informing all forms of tasks can help increasing employees' work commitment.

According to the results of the observation, this very high organizational commitment could be due to the complete facilities provided by the company in helping employees. Besides salary, status, job security, and so on are well managed. So, this makes employees feel their needs are fulfilled, employees feel comfortable and at home to continue working in the company and make work commitments very high.

\section{CONCLUSION}

Based on the results of the research and analysis that have been conducted, it can be concluded that there is a positive and significant relationship between the effectiveness of interpersonal communication, working age and job tenure with organizational commitment. Thus, it can be said that organizational commitment of 50 employees of PT. Pupuk Kalimantan Timur is influenced by the effectiveness of interpersonal communication, working age and work period. The results of this study are in accordance with the theories and the results of previous studies which stated that the effectiveness of interpersonal communication, working age and job tenure are variables that influence organizational commitment.

\section{REFERENCES}

Armstrong, M. 1998. Managing People : A Practical Guide for Line managers. London: Kogan Page.

Azwar, S. 2010. MetodePenelitian. Yogyakarta: PustakaPelajar.

Burnetto, Y., \& Wharton, R. F. 2003. The Commitment and Satisfaction of Lower Ranked Police Officers: Lesson for Management Policing. An International Journal of Police Strategies and Management, 26(1), 43-63.

Burke, R., \& Nelson, D. 1997. Downsizing and Restructuring. Lessons from The Firing Line for Revitalising Organizations. Leadership and Organizational Development Journal, 8(7), 39-64. 
Carmeli, A., \&Gefen, D. 2005. The Relationship between Work Commitment Models and Employee Withdrawal Intentions. Journal of Managerial Psychology, 20(2), 63-86.

Chen, H. G., Chen. E. T., \&Yeh, A. 2003. The Effects of Relationship Commitment and Trust on Business to Consumer Electronic Commerce - The Case of Taiwan.Communication of the International Information Management Association, 3(1), 35-45.

De Ridder, J. A., \& Van den Hoof, B. 2004. Knowledge Sharing in Context: The Influence of Organizational Commitment, Communication Climate and CMC Use on Knowledge Sharing. Journal of Knowledge Management, 8, 117-130.

Downs, C.W. 1990. Communication Audit Questionnaire. Boston: Holbrook.

Drucker, P. 2000. Business Masterminds. London: Dorling Kindersley Limited.

Effendy, O. U. 1986. Dmensi-DimensiKomunikasi. Bandung. : Alumni.

Gamble, J., \& Huang, Q. 2008. Organizational Commitment of Chinese Employees in Foreign-Invested Firms.The International Journal of Human Resource Management ,19(5), 86-91.

Gamon, C. K. 1991. Managing Commitment: Developing Loyalty in a Changing Workplace. Menlo Park: Crisp Publications.

Griffin, R. W. 2002. Management. Boston: Houghton Mifflin Company.

Harcot, J., Krizan, A. C., \& Merrier, P. 1996.Business Communication.(Third Edition). Cincinnati: South-Western Educational Publishing.

Hadi, S. 2004. Metodologi Research Jilid 1. Yogyakarta: Andi Offset.

Hiltrop, J. 1996. Managing The Changing Psychological Contract. Employee Relations, 18(1), 36-44.

Kreitner, R., \&Kinicki, A. 2010.Organizational Behavior. New York: McGraw-Hill.

Luthans, F. 2002. Organizational Behavior.(Ninth Edition). New York : McGraw-Hill.

Mathieu, J. E., \&Zajac, D. 1990. A Review and Meta-Analysis of The Antecedents, Correlataes, and Consequences of Organizational Commitment. Psychological Bulletin, 108, 171-194.

Matin, H. Z., Jandaghi, G., Karimi, F. H., \&Hamidizadeh, A. 2010. Relationship between Interpersonal Communication Skills and Organizational Commitment (Case Study: JahadKeshavarzi and University of Qoma, Iran). European Journal of Social Sciences, 13(3), 387-398.

McShane, S. L., \&Glinow, M. A. V. 2003.Organizational Behavior: Emerging Realities for the Workplace Revolution. New York: McGraw-Hill.

Miner, J. B. 1992.Industrial-Organizational Psychology. Singapore: McGraw-Hill. 
Muthuveloo, R., \& Rose, R. C. 2005.Typology of Organizational Commitment.American Journal of Applied Science, 2(6), 1078-1081.

Northcraft, G. B., \& Neale, M. A. 1990.Organizational Behavior: A Management Challenge. Orlando: The Drydn Press.

Pace, R. W., \&Faules, D. 1994.Organizational Communication.(Third Edition). Englewood Cliiffs: Prentice-Hall.

Pincus, J. D. 1986. Communication Satisfaction, Job Satisfaction, and Job Performance.Human Communication Research, 12, 395-419.

Portalhr.2004.

MembedahPandanganKaryawan

Indonesia.Diaksesdarihttp://www.portalhr.com/people-management/employee relations/membedah-pandangan-karyawan-indonesia/ , 28 Oktober 2011.

Portalhr. 2007. Komunikasi yang EfektifTingkatkanKomitmenKaryawan. Diaksesdari, http://www.portalhr.com/berita/komunikasi-yang-efektif-tingkatkan-komitmenkaryawan/, 30 November 2011

Portalhr. 2007. TrenPenuaanKaryawan: Tips bagiPimpinan HR. Diaksesdari, http://www.portalhr.com/tips/tren-penuaan-karyawan-tips-bagi-pimpinan-hr/, $\quad 28$ Desember 2011.

Prasetyo, E., Nurtjahjanti, H., \&Indrawati, E. S. 2005.KomitmenOrganisasiDitinjau Dari Komunikasi Interpersonal yang Efektif di TempatKerja.JurnalPsikologiUniversitasDiponegoro, 2 (1), 33-39.

Putti, J. M., Aryee S., \&Phua, J. 1990.Communication Relationship Satisfaction and Organizational Commitment.Group and Organization Studies, 15, 44-51.

Rho, E. 2009.The Impact Organizational Communication on Public and Nonprofit Managers Perception of Red Tape.National Public Management Research Conference, 1(1), 1 27.

Robbins, S. P. 2006. Organizational Behavior.(Eleventh Edition).Upper Saddle River: Prentice-Hall.

Roe, R. A., Solinger, N. O., \&Olffen, W. V. 2008.Beyond the Three-Component Model of Organizational Commitment.Journal of Applied Psychology, 93(3), 70-83.

Rumanti, M. A. 2002. Dasar-dasar Public Relation; TeoridanPraktik. Jakarta: PT. Gasindo.

Spaho, K. 2011. Organizational Communication As an Important Factor of Company Success: Case Study of Bosnia and Herzegovina. Business Intelligence Journal, 4(2), 390-393.

Steers, R. M., \& Porter, L. M. 1983.Motivation and Work Behaviour. New York: MacGrawHill. 
Tanajaya, M., \&Noegroho, S. 1995.PerbedaanFaktor FaktorKeterikatanKerjaKaryawanTerhadapOrganisasiDitinjau Dari JenisKelamin. JurnalPsikologi Indonesia.Jakarta :IkatanSarjanaPsikologi Indonesia, 1, 8-16.

Trombetta, J., \& Rogers, D. P. 1988. Communication Climate, Job Satisfaction, and Organizational Commitment The Effects of Information Adequacy, Communication Openness, and Decision Participation. Management Communication Quarterly, 1(4), 494-514.

Van Dyne, L., \& Graham, J. W. 2006. Gathering Information and Exercising Influence: Two Forms of Civic Virtue Organizational Citizenship Behavior. Employee Responsibilities and Rights Journal, 18, 89-109.

Varona, F. 1996. Relationship between Communication Satisfaction and Organizational Commitment in Three Guatemalan Organizations.Journal of BusinessCommunication, $33(2), 111-129$. 